\title{
A crise do capitalismo como crise de subjetividade
}

\author{
Eduardo Weinhardt Pires
}

LAZZARATO, $M$.

Signos, máquinas, subjetividades.

São Paulo; Helsinque: n-1 Edições;

Edições Sesc São Paulo, 213p., 2014

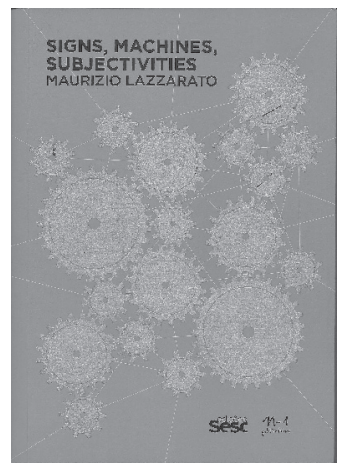

Resumo: Em Signos, Máquinas, Subjetividades, Maurizio Lazzarato busca um novo entendimento do funcionamento do capitalismo e da crise pela qual este passa, acusando a maioria dos autores da teoria crítica contemporânea que se dedicaram ao tema de reféns de uma visão "logocêntrica". O autor recupera ideias de Guattari para explicar o capitalismo neoliberal, com base em processos de subjetivação que se dão no cruzamento de processos de sujeição social e servidão maquínica, concluindo que a crise atual é, portanto, uma crise de subjetividade.

Palavras-chave: teoria crítica; capitalismo; subjetividade; Félix Guattari.

Abstract: The crisis of capitalism as a crisis of subjectivity - In Signs, Machines, Subjectivities, Maurizio Lazzarato seeks a new understanding on how capitalism works and the crisis it is going through, accusing most of authors from the contemporary critical theory of being restrained to a logocentric view. He recovers some of Guattari's ideas to explain neoliberal capitalism based on the crossing between social subjection and machine enslavement, and points out that the current crisis is, therefore, a crisis in subjectivity.

Keywords: critical theory; capitalismo; subjectivity; Félix Guattari. 
Desde 2008 o capitalismo global vem passando por uma crise de difícil superação. Já se sabe que crises cíclicas fazem parte da lógica capitalista, mas esta tem parecido um tanto mais resistente, talvez com raízes mais antigas e robustas do que suporíamos, trazendo impactos que ainda não conseguimos compreender de todo. Não é à toa que diversos autores alinhados com o pensamento da esquerda crítica têm se dedicado a entender e buscar soluções para esse cenário. Lazzarato filia-se a esse grupo, com seu último título publicado no Brasil: Signos, Máquinas e Subjetividades, mas apresenta uma perspectiva bastante diferente quanto às as razões da crise, em comparação ao que já se propôs até agora. Para ele, estamos frente não apenas a uma crise econômica, mas, primeiramente, frente a uma crise de subjetividade.

Sociólogo de origem italiana que vive e trabalha na França, o autor vem se dedicando há anos a estudar o capitalismo contemporâneo. De sua produção recente se destacam: O Governo das Desigualdades, de 2011, As Revoluções do Capitalismo, lançado no Brasil em 2006, e Trabalho Imaterial, de 2001, escrito com Antonio Negri. Também com uma visão crítica sobre o neoliberalismo, escreveu ainda La fabrique de l'homme endetté (2011) e Gouverner par la dette (2014), ambos ainda sem tradução para o português. Datado de 2010, Signos, Máquinas e Subjetividades foi escrito originalmente em francês, mas curiosamente não foi editado na França. Ele foi lançado pela primeira vez apenas em 2014, nos Estados Unidos, pela editora Semiotexte, com o título Signs and Machines, enquanto que a edição brasileira aqui apresentada foi lançada simultaneamente no Brasil e na Finlândia, em uma bem produzida edição bilíngue português-inglês.

Na introdução, Lazzarato nos lembra que já em um seminário de 1984, Félix Guattari havia apontado a subjetividade como ponto central das crises que afligem o capitalismo desde o início dos anos 1970. Crises da "ordem da governamentalidade neoliberal"(p. 15), que levam a um estado de depressão generalizada, um novo "mal do século" (p. 14), no qual o homem empreendedor de si mesmo, nos termos de Foucault (2005), se vê obrigado a assumir a responsabilidade pelos fracassos econômico, social e político do Estado assim como o seu próprio fracasso no mundo dos negócios. A partir dessa perspectiva, torna-se possível compreender o retorno que se observa hoje tanto a ideários pré-capitalistas ou de negação destes, como, principalmente, àqueles fantasmas modernos que acreditávamos já em vias de extinção, tais como o nacionalismo, o racismo e o fascismo.

Trata-se de um problema que os sindicatos e partidos de esquerda não estão conseguindo interpretar e a que não têm podido oferecer soluções, assim como a maioria dos pensadores de esquerda. Para Lazzarato, os autores contemporâneos da teoria crítica, tais como Jacques Rancière, Paolo Virno, Slavoj Žižek, Alain Badiou e Judith Butler, seguem presos a uma visão logocêntrica, que não leva em consideração aqueles elementos essenciais para o funcionamento do capitalismo e da política que não são da ordem da linguagem. Dessa maneira, "fracassaram ao abordar a relação entre capitalismo e processos de subjetivação" (p. 16).

Tomando como principal base as ideias de Guattari - para as quais aliás esta obra pode constituir adequada introdução -, o livro desenvolve-se ao longo capítulos que não 
separam a "produção de subjetividade" da economia ou da política. A subjetividade ocupa, dessa perspectiva, uma posição central no funcionamento do capitalismo, operando com base em dois movimentos opostos e simultâneos, identificados por Deleuze e Guattari: sujeição social e servidão máquinica. Segundo Lazzarato, "é no ponto de intersecção entre eles que a produção de subjetividade se dá" (p. 18).

A sujeição social corresponde ao processo que nos atribui uma identidade, um gênero, um corpo etc. É nela que se dá a produção do sujeito individuado, que no neoliberalismo assume o caráter de "capital humano" e "empresário de si" (p. 27). Já a servidão maquínica opera no sentido oposto, desmontando o sujeito individuado e seus representações, com caráter pré-individual e supraindividual. Corresponde a um processo de dessubjetivação no qual o indivíduo passa a ser uma engrenagem, um componente de um sistema. Nesse contexto, não há espaço para o dualismo sujeito/objeto ou natureza/ cultura. Tanto homem quanto máquina constituem engrenagens intercambiáveis de uma estrutura produtiva, que se agenciam mutuamente.

Dessa maneira, sujeição social e servidão maquínica relacionam-se com "regimes distintos de signos" (p. 38). Enquanto a primeira toma por base "semióticas significantes", principalmente a linguagem, a segunda opera através de "semióticas a-significantes", que não dizem respeito à consciência nem tomam o sujeito como ente referente:

O que importa no capitalismo é controlar os dispositivos semióticos a-significantes (...) através dos quais ele busca despolitizar e despersonalizar as relações de poder (...) Na crise econômica, taxas financeiras a-significantes e índices do mercado de ações dominam, decidindo a vida e a morte dos governos e impondo programas sociais e econômicos que oprimem os governados. As semióticas significantes das mídias, dos políticos e dos especialistas são mobilizados a fim de legitimar, de apoiar e de justificar, diante dos sujeitos individuados - com suas consciências e representações -, o fato de que "não há alternativa". (p. 41)

O capitalismo é, assim, maquinocêntrico, entendendo-se por máquina algo que vai além da bivalência homem/máquina e corresponde a um conjunto de processos interligados, um "agenciamento material e semiótico, atual e virtual", "diagramático" (p. 73), que envolve modelos mais abstratos que a linguagem. Este e outros modos significantes, desempenham um papel político essencial, justificando e dando sentido posterior à lógica maquínica, reconstruindo o sujeito individual nesse preciso contexto, produzindo histórias e discursos que justificam o papel desse sujeito. A maioria dos teóricos contemporâneos, no entanto, falham em entender a essência maquínica do capitalismo, focalizando apenas suas lógicas linguageiras. Embora tenham enterrado o estruturalismo, seguem presos a uma perspectiva logocêntrica.

Neste ponto, vale ressaltar que, apesar de o foco de Lazzarato ser o entendimento do capitalismo neoliberal, as ideias de Guattari apontadas por ele parecem entrecruzar-se 
com o pensamento de alguns autores contemporâneas que buscam romper com qualquer perspectiva ontológica antropocêntrica, como Latour (2015) ou aqueles identificados com a corrente filosófica do realismo especulativo, em especial Bryant (2014) com seu entendimento ontológico do termo "máquina". Também retirando o homem do centro da reflexão, Guattari passa a abordar a subjetividade e a enunciação do "ponto de vista das próprias coisas". Nesse sentido, distingue diferentes tipos de semióticas, que não consideram unicamente a linguagem humana: codificações a-semióticas "naturais" (sistemas cristalinos e DNA, por exemplo), semiologias significantes, incluindo as semiologias simbólicas (ou pré-significantes, gestuais, rituais, produtivas, corporais, musicais etc.), semiologias de significação e, finalmente, semióticas a-significantes (p. 62).

Assim, a subjetividade não é desenvolvida exclusivamente pelas semiologias significantes na construção do sujeito individuado da sujeição social. Pelo contrário, para Guattari, existe uma subjetividade pré-individual, que precede todos os modos de subjetivação e vem sendo sistematicamente ignorada pela linguística e pela filosofia analítica. O entendimento do self, ou do sentido linguístico de si, é posterior a etapas de apreensão de si mesmo que não se dão pela experiência verbal, na qual não há diferenciação entre sujeito e objeto, e que se manifestam continuamente ao longo da vida do indivíduo, em paralelo aos processos de fala e cognição. Nessa perspectiva, a noção consciente de si mesmo, "tem a ver com a junção e a disjunção, a complementariedade e a lacuna entre as partes verbais e não verbais da subjetividade, entre semióticas simbólicas a-significantes e semiologias significantes..." (p. 93).

Contudo, não podemos cometer o erro oposto e subestimar a importância das semiologias significantes na manutenção da ordem capitalista neoliberal através também da sujeição social. Lazzarato aponta novas estratégias de sujeição aparentemente incoerentes, tais como silenciar o cidadão ao fazê-lo falar, excluí-lo chamando-o a participar. "Nas sociedades de segurança, o problema não é a escassez de fala, mas sua superabundância, o consenso e o conformismo que sua circulação pressupõe e produz" (p. 125). Em outras palavras, por mais que o indivíduo tenha voz, ele só pode falar e agir dentro dos âmbitos pré-determinados pelo marketing, pela publicidade e pelas grandes empresas de comunicação, que formam uma grade que não oferece possibilidade de mudança. O espaço público, assim, torna-se saturado por um sem número de discursos e enunciados que, na verdade, impedem a enunciação singular e processos de subjetivação heterogêneos. Para que uma enunciação singular seja realmente possível, deve-se romper com essa grade pré-estabelecida e criar novas clivagens, "deve-se deixar a infinita tagarelice do consenso midiático, forçar rupturas no espaço público" (p. 125).

Para aprofundar a reflexão sobre essa ruptura discursiva, Lazzarato recupera os escritos de Guattari a respeito das ideias de Bakhtin. Radicalizando a diferença entre o linguístico e o extralinguístico apontada pelo teórico russo, denomina a dimensão extra-linguística "função existencial" (p. 175). Mesmo quando não discursiva, esta funciona como motor 
criativo para a enunciação. Em outras palavras, essa dimensão corresponde a uma apreensão de si mesmo e do mundo, da ordem afetiva/existencial, que corresponde a um ponto inominável que serve de partida para qualquer enunciação, qualquer relato ou narrativa.

É no discurso, no entanto, que a existencialização aproxima-se de uma forma, de um corpo, ainda que as lógicas do discurso e do existencial mantenham-se distintas. Uma das principais diferenças entre elas é que "a repetição na lógica discursiva produz sempre discurso, combinações de discurso, enquanto na lógica existencial a repetição ("ritornelo") produz mudanças de estados subjetivos que modelam a subjetividade"(p. 178). Lazzarato aponta como exemplos de ritornelo Lênin e Cristo, que criaram um outro tipo de universo, uma nova atualização possível, que libera um processo de subjetivação heterogênea de ordem coletiva. Ao cruzamento dessas duas lógicas díspares, à sua conjunção que não pode ser apreendida ou articulada como uma relação científica ou cognitiva, Guattari dá o nome de "paradigma estético". Cabe ressaltar aqui que ele não está se referindo a uma experiência estética, mas sim à apreensão do existencial.

Nesse sentido, o discurso, as semióticas significantes, antes de comunicarem ou transmitirem uma mensagem, funcionam como possíveis ritornelos existenciais que, só assim tomados, operam mudanças significativas. Ou seja, para gerar uma mutação subjetiva, os discursos, os signos, devem funcionar como portas de acesso a novas realidades. Neste ponto podemos retornar à questão central do livro: a crise do capitalismo contemporâneo é, na verdade, uma crise na subjetividade. O capitalismo neoliberal não conseguiu articular o sentido discursivo e o existencial, deixando de oferecer uma possibilidade de futuro. Para buscar uma saída, a ação política não deve se concentrar na economia, no social ou no linguístico, mas na produção de subjetividade, buscando realizar uma transformação não apenas discursiva mas existencial. Somente essa ruptura permitirá vislumbrar a construção de outras realidades, que, por sua vez, abrirá a possibilidade e demandariam o desenvolvimento de novas linguagens e novas formas de vida. Na política, o rompimento se manifestaria nas greves, manifestações e revoltas, que, ainda que por apenas um instante, suspendem o tempo e trazem à tona outros possíveis.

Já nos anos 1980, tanto Guattari quanto Foucault, percorrendo caminhos distintos, acabaram concluindo que as únicas questões que poderiam revelar saídas para o impasse no qual nos encontramos eram a produção de subjetividade e a constituição da relação consigo mesmo. E é nessa perspectiva que Lazzarato coloca aquela que para ele é a grande questão política contemporânea:

Como podemos inventar e praticar a igualdade sob essas novas condições de subjetivação? (...) Como podemos inventar e praticar tanto a igualdade como a diferenciação ética (singularização) rompendo ao mesmo tempo com as servidões maquínicas e as sujeições sociais do capitalismo contemporâneo, que exercem esse duplo domínio sobre a nossa subjetividade? (p. 213) 
Lazzarato, não nos dá a fórmula de resolução do impasse e que nos encontramos mas oferece um nova perspectiva para interpretar a crise e, assim, indica novos caminhos para buscar uma saída.

Eduardo Weinhardt Pires é mestrando do Programa de Estudos Pós-Graduados em Comunicação e Semiótica da PUC-SP.

edufwp@hotmail.com

\section{Referências}

BRYANT, Levi R. Onto-Cartography: An Ontology of Machines and Media. Minneapolis: University of Minnesota Press, 2014.

FOUCAULT, Michel. Nascimento da Biopolítica. São Paulo. Martins Fontes, 2008.

LATOUR, Bruno. Reagregando o Social: uma introdução a teoria Ator-Rede. Salvador: Edufba, 2015. 